\title{
Global Aspects of the Gastronomic Trends and Innovations
}

\author{
Miroslava Kostkova ${ }^{l, *}$, and Pavlina Pellesova ${ }^{l}$ \\ ${ }^{1}$ Silesian University in Opava, School of Business Administration in Karvina, Department of Tourism \\ and Leisure, Univerzitni nam. 1934/3 73340 Karvina, Czech Republic
}

\begin{abstract}
.
Research background: The current conditions of globalization come to a necessity of flexible adaptation and efficient use of the resources. The companies compete with each other and try to attract customers through an attractive offer that determine the global trends.

Purpose of the article: The aim of the article is to examine the introduction of new gastronomic trends and innovative solutions into the offer of restaurants in the Czech Republic and their acceptance on the customer side. Methods: The article examines the opinion about the product, marketing and organizational innovations, their economic success and attractiveness of the offer to clients. Marketing research based on the online questionnaire survey between providers of the gastronomic services and the customers is used. Explored was the relationship between the qualitative factors of the service and the repeated visit by consumers from the perspective of catering service providers. The Chi quadrate test of independence is used for the evaluation of the research question and two hypotheses as well. The method of comparison including the results of previous research and the synthesis of research conclusions are used.

Findings \& Value added: The identification of new trends can be an inspiration for entrepreneurs in the development of new products and in the introduction of service innovations. The definition of the significant gastronomic trends of Czech gastronomic companies can be used for gastronomy business and can bring a higher customer satisfaction and tourist attendance for the establishments and destination.
\end{abstract}

Keywords: globalization; gastronomy trends and innovations; research; services

JEL Classification: $M 21 ; Z 32$

\section{Introduction}

The current globalized environment causes constant changes in all market entities such as institutions and companies. Their flexible adaptation to the current conditions of

\footnotetext{
*Corresponding author: kostkova@opf.slu.cz
} 
globalization is becoming a necessity and it is determined by the skilful use of resources. Companies compete with each other and try to attract customers through an attractive offer that is influenced by global trends. The competitiveness of a company is an essential indicator of the efficiency and management of business entities. The massive use of the Internet and new technologies as well as the expansion of their availability is a key phenomenon of globalization that poses a change in the nature of production and in the production process. Globalization brings a change in eating habits that has been changing since the beginning of humanity but that has never been as forceful as it is today. Trends are based on global megatrends that operate in various areas of life and that change the world around us.

Exploring the development of trends in gastronomy, socio-economic factors and lifestyle is the goal of a number of current projects that deal with the prediction of trends in the hotel industry, catering and business in tourism. One of the goals of the project "Trends and innovations in tourism in the Czech Republic" is to examine new gastronomic trends and the level of introduction of innovative solutions in Czech restaurants, determine their benefits and identify attitudes and acceptances of new gastronomic trends on the part of operators and customers. The article presents the results of a survey of customers and operators of restaurant facilities on the product, marketing and organizational innovations in the field of restaurant offerings, moreover, it analyses the relationship between qualitative factors of the company environment and repeated visits from the perspective of gastronomic service providers which can be used as in business as in practice in creating new products to increase customer's satisfaction and tourist attendance.

\section{Theoretical background}

Globalization is one of the most current and discussed topics of the present which intensely affects the lives of all the inhabitants of our planet. Within advanced economies, globalization affects almost all areas of citizens' lives with a direct impact on the economic, social or political spheres. Globalization is also a major multiplicator of international trade and the associated flow of goods, services, financial and human capital. Klieštik et.al. (2018) confirms the interconnection of the world and the changes of contemporary civilization in all social areas of society and discusses globalization as the process of creating structures in individual areas of social life and human activities, increasing their complexity and gradually interconnecting these sub-global structures (Nová, 2020). The globalization of economic activities is presented mainly by the interconnection of production and markets of different countries mainly in the field of international trade in goods and services, the flow of information and movement of capital (Lechner, Boli, 2006). The consequence of globalization from an economic point of view (Musová, Poliačiová, 2018) is the development of international trade and the influence on the creation of the offer of organizations influenced by transnational tendencies.

The development of international trade is also related to the development of tourism which is considered a form of international trade. The article points out the influence of globalization trends on the creation of an important area of the tourist offer that is restaurant companies, in places of concentrated tourist demand, where this offer strongly influences also the tourist attendance the destination. According to Brelik, Grinberga-Zalite (2019) the role that tourism can play in the economy depends on its competitive position. The development of competition in the market of tourist services, both local, regional, internal, European and global, forces market participants to seek new forms of shaping their competitiveness. Identifying trends that change travel helps managers better understand customer needs and remain competitive (Bowen \& Whalen 2017). Costa \& Buhalis (2006) agreed, that examining trends in the tourism is the basis for determining its competitiveness. 
Filimonau et. al. (2017) talks about the need for managerial decision-making to include new trends in the offer, which is a decisive factor for consumer choice. A competitive region is a region that creates a favourable environment for the development of entrepreneurship and innovation in a market economy and enables companies to achieve high economic efficiency, thanks to which it increases the standard and quality of life in the region. This approach refers to the concept of tourist attractiveness of areas and includes a group of elements related to tourism, which is of interest (demand) to potential tourists.

The aim of the paper is to identify new trends in the field of gastronomic services and their impact on tourist attendance. Castillo-Manzano et. al. (2020) researched Michelinstarred restaurants as a new trend used to measure a tourist destination's culinary standard. Their findings show that restaurant quality is more important than quantity in the gastronomy-tourism relationship and that starred restaurants are a strong attraction for foreign tourists. Meneguel et al. (2019) claims that high-quality restaurants with the implementation of innovation stimulate the creation and development of gastronomic tourism. Companies, therefore, strive to obtain a quality certificate and adapt their offer to new trends. Kivela and Crotts (2006) talks about the importance of connecting tourism and gastronomy and the influence of gastronomy on the experience of the visitor from the destination.

Gastronomic tourism is one of the leading tourist trends, as confirmed by many authors. Okumus et. al. (2018) examines international and national collaboration of food-related management, gastronomy technology and marketing and notes that it has been growing. A well-publicized region and gastronomic events influence the attendance of the region and the consumption of not only gastronomic services. This reflects the multiplier effect of gastro tourism. Marocu and Paci (2013) explain the impact on tourists' decisions when choosing a specific destination, gastronomic attractions are into crucial determinants of tourism attendance. Romero et. al. (2019) studied the innovative behaviour of restaurant firms and confirm that coopetition fosters product innovation in restaurant companies.

Competition between the restaurants brings process innovations and participation in restaurant chains stimulates process innovation. Entrepreneurs with intrinsic entrepreneurial motivation favour product innovation in their restaurants and investments in IT and in staff training are observed to be the main determinants of product and process innovation in the restaurant industry. The rivalry between regions is now increasingly sophisticated (Botlikova, 2018). The winning areas are those that favour new management methods and are able to realize their potential and work with trends that affect the tourism market.

Megatrends that affect gastronomy, the food industry and market include, for example, urbanization, digitization, individualisation, neoecology, the interest in a healthy lifestyle, globalization, the movement to change working conditions and gender equality. New trends include so-called snackification (the tendency not to divide the day only into three main meals), linking art, design and food, that leads to innovation, the availability of quality food and its cultivation in cities, food as a bridge between cultures, sustainable diet that does not burden climate, the end of the plastic age at various levels of gastronomy, hyperlocal cuisine, authenticity, sustainability and autonomy, fermented drinks and natural wines, sourdough bread, nutritionally rich children's menu, fast good, umami taste and smoky aroma, the care for the origin and higher quality of meat, interactive gastronomy - in the open kitchen, the experience and personal contact with restaurant and chef are offered (Kol., 2019). The trends presented by Ana (2017) in her research focusing on Central European customers also include:

- use of the Internet to obtain information, make reservations and order and services,

- popularity of discount portals,

- growing interest in experiences,

- discovering unique places and their gastronomy, 
- increasing interest in gastronomic tourism (visits of gastronomic and food festivals, wine tourism, beer tourism, farmers' market, etc.) and learning about culture through food,

- growing tourist demands for services (quality/price ratio),

- expanding the experience of visitors and guests, searching for interesting and trendy events,

- $\quad$ significant seasonality.

This paper deals with the examination of globalization tendencies that, under the pressure of customer demand and changes in their preferences, are reflected in the partial part of the tourism offer, specifically in gastronomy. It examines the development of gastronomic trends and the level of implementation of the process, marketing and product innovation in gastronomic services.

\section{Methods}

In the spring of 2020, a survey was conducted about the introduction of modern gastronomic trends in independent restaurants and hotel restaurants of 4 selected tourist destinations in the Czech Republic, which was the first phase of research within the project "Tourism Trends and Innovations in the Czech Republic". It follows up on the previous project "Trends in Tourism in the Moravian-Silesian Region". This created the possibility of comparing the specific results with a focus on research of trends in gastronomy.

The selection of a representative sample was a quota and it was determined from the database of restaurants and hotels in the 4 largest cities in the Czech Republic, assuming a significant tourist concentration and customer demand. The aim of the survey was not only to evaluate the attitudes of representatives of both independent and hotel restaurants to new gastronomic trends and their benefits but also to determine the level of introduction of new trends and innovations to the offer of restaurants. The research question was whether the introduction of modern gastronomic trends differs due to the size and type of restaurant facilities and which gastronomic trends are considered the most important. The opinion of respondents - representatives of selected restaurants on the product, marketing and organizational innovations, their specific focus and economic success were also examined. The research area was the gastronomic offer of independent and hotel restaurants. The aim of the comparison was to find out the development of demand-side preferences for innovations in the offer of companies, the relationship of visitors and operators to the introduction of innovations in supply, the impact of quality and certification on the grow of demand and, on the supply side, the factors influencing repeated visits. The survey involved 44 restaurants, $60 \%$ of representatives of limited liability companies, $30 \%$ of joint-stock companies and $10 \%$ of sole proprietors, of which $40 \%$ of independent companies. Most companies were from Prague (40\%), as well as from Brno, Ostrava and Pilsen (20\% each), with 40 to 350 seats in the restaurant, one-fifth of respondents employs up to 10 employees, $40 \%$ up to 50 employees and $40 \%$ up to 250 employees.

The relationship and the existence of dependence between the opinions of the representatives of the interviewed companies on qualitative factors motivating customers to repeat the visit using the Chi Quadrat test were examined. A research question and two statistical hypotheses were identified and the hypotheses were evaluated using the Pearson coefficient at the significance level $\alpha=0.05$. (1).

$$
\chi^{2(r-1) *(c-1) *(1-\alpha)}<\chi^{2}
$$


The expected value of the observation is based on the mathematical relation (2) and (3), the value of ni. and the value of $\mathrm{n} . \mathrm{j}$ is expressed as the sum of the individual observations.

$$
\begin{gathered}
e_{i j}=\frac{n_{i \cdot *} n_{\cdot j}}{n} \\
n_{i .}=\sum_{j=1}^{s} n_{i j} \quad n_{\cdot j}=\sum_{i=1}^{r} n_{i j}
\end{gathered}
$$

The data were processed using the SPSS program, both the method of exploratory research, analysis and synthesis and the method of generalization and prediction of further development were used. The secondary information was based on studies about the development of tourist indicators as well as on data from the Czech Statistical Office.

\section{Results and Discussion}

The aim of the paper was to explore and find new trends and innovations in the field of catering services.

The results of the questionnaire survey showed that for $38 \%$ of respondents representatives of restaurants, the trend is perceived as a characteristic direction or sequence of developments, which is characterized by a long-term trend. Companies confirm that trends have a long lifespan and that are observable in several market areas and customer activities. They perceive the trend as a general direction in which something is moving or changing.

The majority of surveyed business representatives $(80 \%)$ agrees that without monitoring consumer trends the competitiveness cannot be maintained; monitoring trends and introducing new products into the offer increase both sales and traffic and positively affects customer satisfaction. Respondents replied that they focus on introducing modern trends into supply, they follow new trends whose introduction is a current necessity; for $17 \%$ of respondents this is not a priority and some of them mention that it is dependent on their financial capabilities. Only a very small proportion of respondents distance themselves from the introduction of innovations and the following modern trends; in other words, we deal with a neutral position of $8 \%$. The restaurants regularly add news to the menu and prepare thematic gastronomic events using the training and courses organized for their members by professional associations. When evaluating the success of established trends in modern gastronomy, homemade seasonal drinks and meals $(62 \%)$ were evaluated as the best ones followed by Czech traditional cuisine, drinks and desserts (43\%), wine or beer tasting (40\%), taste food pairings and butcher's feasts (both $39 \%$ ), mixed drinks (38\%), pairing food with wine or beer (37\%) and tasting new dishes (43\%). The most significant economic benefits came from events focused on homemade seasonal drinks and meals $(61 \%)$, meals prepared in front of guests and Czech traditional cuisine $(60 \%)$. Over the last 3 years, the most frequently introduced concepts were exotic dishes $(87 \%)$ and foreign national cuisine days $(63 \%)$. According to the respondents - representants of the establishments, for the repeated guest visit of the restaurant is decisive: the taste of food and drinks (75\%), the staff approach and colorful offer and good quality of food (54\%); new technologies and prices are only in the $3^{\text {rd }}$ place.

Innovation is a concept that contains the change. It can mean improvement, and it is undoubtedly associated with the active work of people. Among the innovations, the 
introduction of product innovation in the form of the introduction of foreign cuisine, seasonal dishes and a change in the appearance of food $(89 \%)$ were mentioned as the most frequent ones.

Among the marketing innovations, the changes in design and surrounding of catering establishments, changes in outdoor advertising, high activity on social networks, participation in competitions and fan pages, the use of various sales internet portals and changes in websites were mentioned significantly. On the other hand, advertising on social networks was among less frequent innovations. In total, there were $19 \%$ of respondents who did not consider involvement in national sales systems (such as national Czech Specials) or international competitions, they will not create a new logo (the current one is considered effective and promotional enough) and who did not want to invest in advertising in broadcast media due to high costs.

Among the organizational innovations the introduction of new equipment and new organization of sales and product offerings (e.g. change of interior design, table arrangement, children's corner, front garden etc.) were most often mentioned followed by the investment in improving clothing for staff, service aesthetics and, in the future, the introduction the catering services and home and business dishes delivery.

From technological innovations, companies decided to purchase new technical and technological equipment and to introduce new recipes and procedures for food preparation (e.g. fit, eco and new flavours of food and beverages). In the near past, most of them introduced an ecological approach to business, new technical and technological devices and equipment. In the field of waste management, all the surveyed companies are involved, most often within the framework of mandatory legislation, some of them try to engage in ecological approach also their clients $(27 \%)$. But any of them the EMS environmental management does not systematically apply.

Sources of ideas for innovative solutions are most often found together with employees $(81 \%)$, ideas are developed and solved together, taking into consideration the customer's opinions (65\%) and monitoring competition and market trends $(64 \%)$ are significant. Financing of innovations is most often provided from own resources $(41 \%)$, followed by suppliers of equipment, bank loans and EU resources (22\%). The most frequently cited reasons for not introducing innovations are the following ones: the lack of funds $(45 \%)$, the lack of knowledge and ideas (21\%), too small size company (11\%) and we also found an answer of the type: we do not have a need (5\%).

After the introduction of innovation, $43 \%$ of the surveyed representatives of gastronomic companies feel an improved company image and a higher degree of competitiveness and $35 \%$ of representatives state that, they have not experienced any significant changes with the introduction of innovation - the situation is stable, they have not lost market and maintained their market position.

Table 1. The decisive factor for the repeated visit/repurchase of the service from the point of view of the customers and catering representatives.

\begin{tabular}{|c|c|c|}
\hline $\begin{array}{c}\text { Rank of } \\
\text { importance }\end{array}$ & Point of view of the customers (in 2017) & $\begin{array}{l}\text { Point of view of the restaurant } \\
\text { reps (in 2020) }\end{array}$ \\
\hline 1. & $\begin{array}{c}\text { A plenty of space, cleanliness, order and } \\
\text { comfort }(96 \%)\end{array}$ & $\begin{array}{l}\text { A speed of service } \\
(94 \%)\end{array}$ \\
\hline 2. & $\begin{array}{l}\text { A professional employee performance, good } \\
\text { language skills and clear communication } \\
(64 \%)\end{array}$ & A reasonable price $(82 \%)$ \\
\hline 3. & A possibility of online booking ( $38 \%)$ & $\begin{array}{c}\text { A staff empathetic approach } \\
(77 \%)\end{array}$ \\
\hline 4. & A reasonable price/quality ratio $(22 \%)$ & \\
\hline Unimportant & & A perfect language skill (57\%) \\
\hline
\end{tabular}


A comparison of the opinions of customers (research from 2017) and representatives of restaurant facilities (2020) on the factors influencing customers' purchasing decisions was made. A comparison of factors that may influence customers' decisions to revisit/purchase a service from the perspective of customers and restaurant representatives is given in Table 1.

Subsequently, the relationship between the examined service quality factors (staff access evaluation, environmental indicators and quality indicators of providing service) and the possibility of the next visit of guests or the repeated purchase of the service using the Chi Quadrate test of independence evaluated was evaluated, from the perspective of the catering companies.

A research question was defined and two hypotheses were expressed:

RQ1: Which of the following qualitative factors of the service leads to the repeated visits of guests in restaurant establishments?

Hypothesis $\mathrm{H}_{0}$ : Repeated guest visits do not depend on the determined qualitative factors of the service.

Alternative hypothesis $\mathrm{H}_{1}$ : The repeated visit of guests depends on the determined qualitative factors of the service.

Table 2 summarizes the results of the Chi Quadrate independence tests. From these values it is clear that there is a statistically significant influence of the monitored service quality factors on the repeated visit of guests in the case of the indicators "speed of service", where the test criterion exceeded the critical value.

Table 2. The results of the Chi Quadrate test of the influence of quality indicators on repeated visit.

\begin{tabular}{|c|c|c|c|c|}
\hline Quality indicators & $\begin{array}{c}\text { Critical } \\
\text { value }\end{array}$ & $\begin{array}{c}\text { Test } \\
\text { criterion }\end{array}$ & $\begin{array}{c}\text { Asymp. } \\
\text { Sigma }\end{array}$ & Result \\
\hline Staff & & & & \\
\hline Professional behaviour & 5.99 & 1.49 & 0.48 & independence \\
\hline The speed of serving & 5.99 & 26.15 & 0.000003 & dependency \\
\hline Excellent language skills & 5.99 & 1.87 & 0.43 & independence \\
\hline Empathetic approach & 5.99 & 4.17 & 0.21 & independence \\
\hline $\begin{array}{c}\text { Knowledge of the supply and the ability to } \\
\text { provide full information }\end{array}$ & \multicolumn{5}{|c|}{ It is not possible to determine whether the test } \\
conditions were not met
\end{tabular}

Representatives of the selected restaurants consider the "quick service" as a factor influencing repeated customer visit. They assume that the factor of "excellent language skills" is less important because the direct interaction between the staff and customer facilitates the understanding of the customer's requirements. In the restaurants, the menu is also adapted to foreign clients, there are various language versions of the menu.

In the case of examining the dependence of repeated visit/purchase of services on indicators such as a professional approach, empathetic approach, good knowledge of the offer 
and ability to provide full information, design, cleanliness and order of the environment, parking options, attractiveness of the offer, menu for children, reasonable prices of services and good price/quality ratio, the dependence was not confirmed and the alternative hypothesis $\mathrm{H}_{1}$ was not accepted. The Hypothesis $\mathrm{H}_{0}$ was confirmed so.

The survey showed the same opinion of the representatives of catering establishments on the importance of quality indicators for repeated guest's visit.

\section{Conclusion}

The results of the survey point to the influence of globalization trends on the creation of tourism offer in the provision of gastronomic services in the Czech Republic. This can serve not only to adapt the offer to residents but also to tourists because the largest revenues are realized during the tourist season and during social events and traditional holidays and celebrations (e.g. vintage, slaughter feasts, harvest festivals, Easter, Valentine's Day, etc.).

From the findings of surveys conducted in 2017 and 2020, as the most important trends in gastronomy we can notice the following ones: widespread use of the Internet and the popularity of discount portals, interest in gastro and food experience and a significant increase in the interest in gastro events (gastro festivals, farmers' markets, etc.). Good references about the company and the good promotion of the offer on the Internet, the possibility of modern communication with clients (via the web and mobile applications), the great emphasis placed on quality staff and flexible changes of the offer according to change in the client preferences play an important role. The majority of respondents (clients and company reps) consider the quality certification as beneficial in terms of improving the company's image and the quality certificate is considered as a mark of the company's quality.

New trends on the supply and the demand side of hospitality services have been identified. It was confirmed that the possibility of modern communication with clients (via the Internet and mobile applications) and quick service play an important role in the repeated visit and the purchase of service. Representatives of catering services share the same opinion about the importance of providing quality service for the repeated guest's visit which is an important factor of a business success.

The dependence between the repeated company visits and the professional performance of staff and environmental factors (design, cleanliness, parking options, environmental comfort) and supply (offer for children, reasonable prices and price/quality ratio) was not statistically confirmed, conversely, quick service and the clean environment were confirmed as decisive factors that influences the next visit.

The survey showed that changes in the demand and changing customer needs force companies to prepare their offer in time, to be competitive and therefore many companies are constantly adapting their offer to new trends. The majority of catering providers agree that competitiveness cannot be maintained without following new consumption trends. The interest in new trends and application of innovations in the offer of gastronomic services is growing. The research into the development of tourist trends and the application of innovation in tourism in the Czech Republic and the ability of the companies to adapt themselves to the new situation in the tourism market will continue. The aim will be to update the identified trends which will be presented to experts by sharing research results and offering participation in solving specific tasks in the field of innovation. The identification of new trends can be an inspiration for entrepreneurs in the development of new products and in the introduction of service innovations that could increase their business success and thus the number of destination visitors. 
The article is created with the support of the Ministry of Education, Youth and Sports of the Czech Republic in the framework of Institutional Support for the Long-Term Conceptual Development of the Research Organization in 2017-2020.

\section{References}

1. Ana, M. I. (2017). Tourism industry in the new Europe: Trends, policies and challenges. Proceedings of the 11th International Conference on Business Excellence - Strategy, Complexity and Energy in Changing Times (pp. 493-503). Warsaw, Poland, 1(1).

2. Botlikova, M. (2018). Tourism in the context of sustainability. Proceedings of the 19th International Scientific Conference on International Relations - Current Issues of World Economy and Politics (pp. 72-78). Smolenice, Slovak Republic.

3. Bowen, J., Whalen, E. (2017). Trends that are changing travel and tourism. Worldwide hospitality and tourism themes. Bingley: Emerald Group Publishing LTD, 9(6), 592602.

4. Buhalis, D., Costa, C. (2006). Tourism management dynamics: Trends, management, and tools. Boston: Elsevier Butterworth-Heinemann.

5. Conrady, R., Buck, M. (2011). Trends and issues in global tourism 2011. Heidelberg: Springer.

6. Castilo-Manzano, J., Castro-Nuno, M., Lopez-Valpuesta, L., Zarzoso, A. (2020). Quality versus quantity: An assessment of the impact of Michelin-starred restaurants on tourism in Spain. Tourism Economics, no. 1354816620917482.

7. Filimonau, V., Lemmer, C., Marshall, D., Bejjani, G. (2017). Restaurant menu redesign as a facilitator of more responsible consumer choice. Journal of Hospitality and Tourism Management, 33, 73-81.

8. Kliestik, T., Kovacova, M., Podhorska, I., Kliestikova, J. (2018). Searching for key sources of goodwill creation as new global managerial challenge. Polish Journal of Management Studies, 17(1), 144-154.

9. Kivela, J., Crotts, R. (2006).Tourism and gastronomy: gastronomy's influence on how tourist experience a destination. Journal of Hospitality and Tourim, 3(30), 354-377.

10. Kol., MMR ČR (2019, sept. 3). Globalizace v cestovním ruchu. Retrieved from: https://www.mmr.cz/MMR/media/MMR_StaryWeb/import/Cestovn\%C3\%AD\%20ru ch/Dotace\%20a\%20programy/Programovac\%C3\%AD\%20obdob\%C3\%AD\%20200 4\%20-\%202006/GetFile37.pdf

11. Lechner, F., Boli, J. (2004). The globalization reader. Malden: Blackwell.

12. Marrocu, E., Paci, R. (2013). Different tourists to different destinations. Evidence from spatial interaction models. Tourism Management, 39, 71-83.

13. Meneguel, A., Cinthia Rolim, C., Mundet, L., Aulet, S. (2019). The role of a highquality restaurant in stimulating the creation and development of gastronomy tourism. International Journal of Hospitality Management, 83, 220-228.

14. Musova, Z., Poliacikova, E. (2018). Consumers' perception of digital marketing tools. Proceedings of the 15th Annual International Scientific Conference on Marketing Identity-Digital Mirrors (pp. 430-440). Smolenice, Slovak Republic.

15. Nova, M. (2020). Globalization - its influences \& impacts on specific regions of Africa. Proceedings of the 19th International Scientific Conference Globalization and Its 
Socio- Economic Consequences - Sustainability in the Global-Knowledge Economy. Rajecke Teplice, Slovak Republic, 74, no. 06020.

16. Ma, F. (2018). Food and gastronomy research in tourism and hospitality: A bibliometric analysis. International Journal of Hospitality Management, 73, 64-74.

17. Romero, I., Porto G., Igone M. Z., Iturriagagoitia, J. (2019). 'Cookpetition': Do Restaurants Coopete to Innovate? Tourism Economics. 6(25), 904-922. 